[Agr. Biol. Chem., Vol. 28, No. 2, p, 82 89, 1964]

\title{
Comparative Study on the Changes of the Casein Fractions on Heating
}

\author{
By Umeo Yoshino, Mizuho Samuro, Kunio Yamauchi \\ and Tomokichi Tsuco \\ Department of Agricultural Chemistry, Faculty of Agriculture, \\ The University of Tokyo, Tokyo \\ Received April 23, 1963
}

\begin{abstract}
The effects of heat on the sodium $\alpha s^{-}, \kappa$ - and $\beta$-caseinate solutions were examined. The liberation of non-protein nitrogen due to heating was considerably less in $\beta$-casein than in $\alpha s-$ or $\kappa$-casein. No great difference was found among the casein fractions as to the liberation of phosphorus by heating. By heating at $140^{\circ} \mathrm{C}$ for sixty minutes, nearly all phosphorus in each casein was liberated. The accelerating effects of heat were observed on the digestibility of $\kappa$-casein with trypsin and of $\alpha s^{-}$and $\beta$-caseins with pepsin. $\kappa$-Casein, when heated at $120^{\circ} \mathrm{C}$ for thirty minutes, lost the ability to stabilize as-casein to calcium ion. Electrophoretic and sedimentation analyses were also performed with caseins heated at different temperatures.
\end{abstract}

Casein exists in milk in the form of a mixture or a complex of several casein fractions. $k$-Casein is the main component of calcium-soluble (or -insensitive) a-casein and is responsible for the stability of casein $\mathrm{mi}$ celle or as-casein ${ }^{1,2)}$.

Heating is the most important step in the processing of milk. The studies on the heatinduced changes in separated casein fractions will afford information on the heat-induced change of milk protein, especially on the mechanism of heat coagulation of milk. The effects of heat on casein have been studied extensively ${ }^{3-7)}$, but data on the separated casein fractions, particularly on $\kappa$-casein fraction, are limitted. Recently Zittle ${ }^{8)}$ reported

\footnotetext{
1) D.F. Waugh, Discusions Faraday Soc., No. 25, 186 (1958).

2) J. Long. Q van Winkle and I.A. Gould, J. Dairy Sci., 41, 317 (1958).

3) M.M. Fitzpatrick and R.A. Sullivan, J. Dairy Sci., 40, 1262 (1957).

4) L. Murthy, E.O. Herreid and R. McL. Whitney, J. Dairy Sci., 41, 1324 (1958).

5) G.R. Howat and N.C. Wright, Biochem. J., 28, 1336 (1934).

6) K. Yusa, Jap, Zootech. Sci., 27, 197 (1957).

7) K. Yamauchi and $\Gamma$. Tsugo, ibid., 32, 311 (1961).

8) C.A. Zittle, J. Dairy Sci., 44, 2101 (1961).
}

the effect of heat on the micelle-stabilizing action of $\kappa$-casein. Belec and Jenness ${ }^{9)}$ reported an extensive study on the heat dephosphorization of whole casein and separated $a$ - and $\beta$-casein fractions.

In our earlier paper ${ }^{7)}$, the changes of the electrophoretic patterns of unfractionated casein when heated with or without sugars and whey proteins were studied. The present report describes the effects of heat on as-, $\kappa$ - and $\beta$-casein fractions with respect to their changes in the solubility in the presence of calcium ion, the electrophoretic and sedimentation properties and the digestibility. The liberation of nitrogen and phosphorus from the fractions by heating was also determined.

\section{MATERIALS AND METHODS}

The $a^{-}$and $\beta$-casein fractions were prepared fom acid casein by the urea method of Hipp et al. ${ }^{10}$ ) The $a^{s}$ and $\kappa$-cacein fractions were prepared from a

9) J. Belec and R. Jenness, J. Dairy Si., 45, 12 (1962).

10) N.J. Hipp, M.L. Groves, J.H. Custer and T.L. McMeekin, ibid, 35, 272 (1952). 
single lot of $a$-casein by the method described by Long et al. ${ }^{2}$ with a slight modification. A $3 \%$ sodium a-caseinate solution was made $0.20 \mathrm{M}$ with respect to calcium chloride by the dropwise addition of $2.0 \mathrm{M}$ calcium chloride at $4^{\circ} \mathrm{C}$ and $\mathrm{pH}$ 6.8. The solution was allowed to stand overnight. The supernatant, separated by decantation from the precipitated ascasein, was warmed to $25^{\circ} \mathrm{C}$ and centrifuged for sixty minutes in a Spinco Model $\mathrm{L}$ centrifuge (No, 21 Rotor) at 21,000 r.p.m. The supernatant ( $\kappa^{\text {-casein fraction) }}$ was dialysed for forty-eight hours at $4^{\circ} \mathrm{C}$ aggainst distilled water to remove calcium. $\kappa$-Casein was then precipitated by bringing the $\mathrm{pH}$ to 4.6 . It was dissolved again with a small amount of $0.1 \mathrm{~N}$ sodium hydroxide and dialysed against distilled water. $\kappa^{-}$ Casein, thus prepared, contained $\lambda$-casein and was referred to as crude $\kappa$-casein by Long et al. ${ }^{2)}$ The precipitated as-casein was suspended in water and was dissolved by adding solid potassium oxalate to a concentration of $0.15 \mathrm{M}$ at $\mathrm{pH} 7.0$. Calcium oxalate precipitated was removed by centrifugation. The solubilized as-casein was precipitated at $\mathrm{pH} 4.6$ with hydrochloric acid. The precipitate was washed twice with water, dissolved with sodium hydroxide at $\mathrm{pH}$ 6.8 and dialysed against distilled water for forty-eight hours at $4^{\circ} \mathrm{C}$. The dialysed solutions of sodium as-, $\kappa$ - and $\beta$-caseinate were freeze-dried.

The phosphorus content and $\mathrm{P} / \mathrm{N}$ ratio were $1.16 \%$ and 0.074 for $\alpha^{-}, 0.56 \%$ and 0.036 for $\kappa^{-}$, and $0.68 \%$ and 0.043 for $\beta$-casein, respectively.

These freeze-dried caseins were dissolved in water, the $\mathrm{pH}$ being adjusted to 6.8 with $0.1 \mathrm{~N}$ hydrochloric acid or sodium hydroxide. Aliquots of sodium caseinate solutions were pipetted into glass tubes, sealed and heated in a paraffin bath. The tubes were cooled in tap water immediately afterwards; then opened and subjected to analyses.

The nitrogen was determined by the micro-Kjeldahl method. The phosphorus of casein fractions was analysed by the colorimetric method after digestion with sulfuric acid and hydrogen peroxide ${ }^{(1)}$. The electrophoretic analyses of the casein fractions were performed with a Hitachi HTD-1 apparatus at $6^{\circ} \mathrm{C}$ in veronal buffer ( $\mathrm{pH} 8.55$, ionic strength 0.1 ). Sedimentation studies were conducted with a Spinco Model E centrifuge at room temperature $\left(16^{\circ} \sim 18^{\circ} \mathrm{C}\right)$ in phosphate buffer ( $\mathrm{pH} 7.5$, ionic strength 0.2).

11) M. Nakamura, J. Agr. Chsm. Soc., Japan. 24, 1 (1950).

\section{RESULTS}

\section{Liberation of Non-protein Nitrogen and Phos-} phorus.

Twenty $\mathrm{ml}$ portions of $1 \%$ sodium caseinate solution were heated at temperatures ranging from $100^{\circ}$ to $140^{\circ} \mathrm{C}$ for periods up to sixty minutes. Fifteen $\mathrm{ml}$ of the heated solution was then mixed with $15 \mathrm{ml}$ of $24 \%$ trichloroacetic acid (TCA). The mixture was fltered and nitrogen in the filtrate (non-protein nitrogen; NPN) was determined. The phosphorus in the filtrate was analysed directly without digestion. The results were expressed as percentage to the total nitrogen and phosphorus, respectively (Figs. 1, 2) .

By heating, NPN increased in each casein fraction. The increase was most in $\kappa$-casein and least in $\beta$-casein. The amount of liberated phosphorus by heating was nearly the

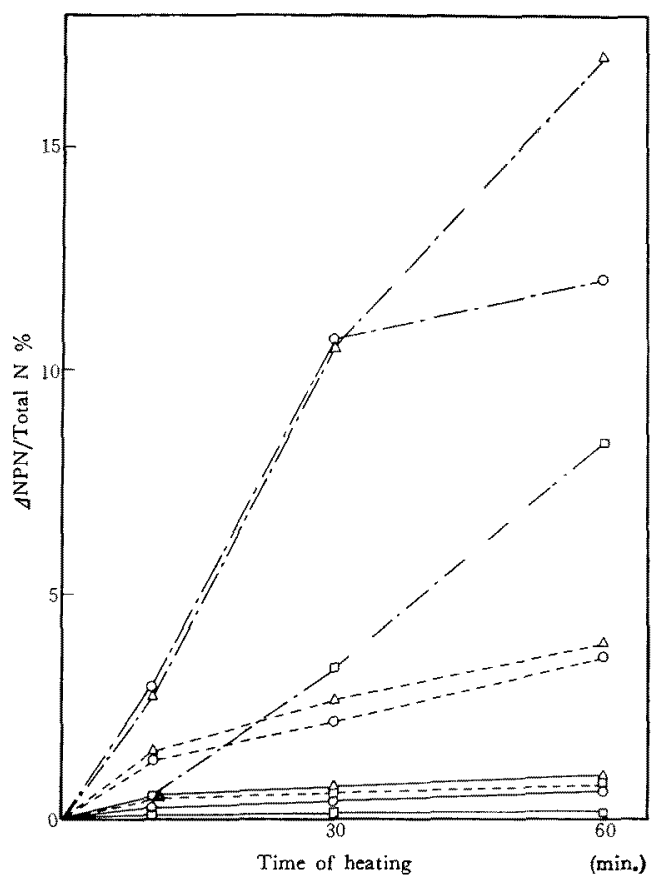

FIG. 1. Liberation of NPN from Caseins by Heating.

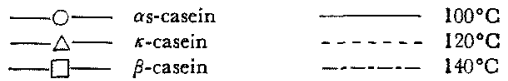




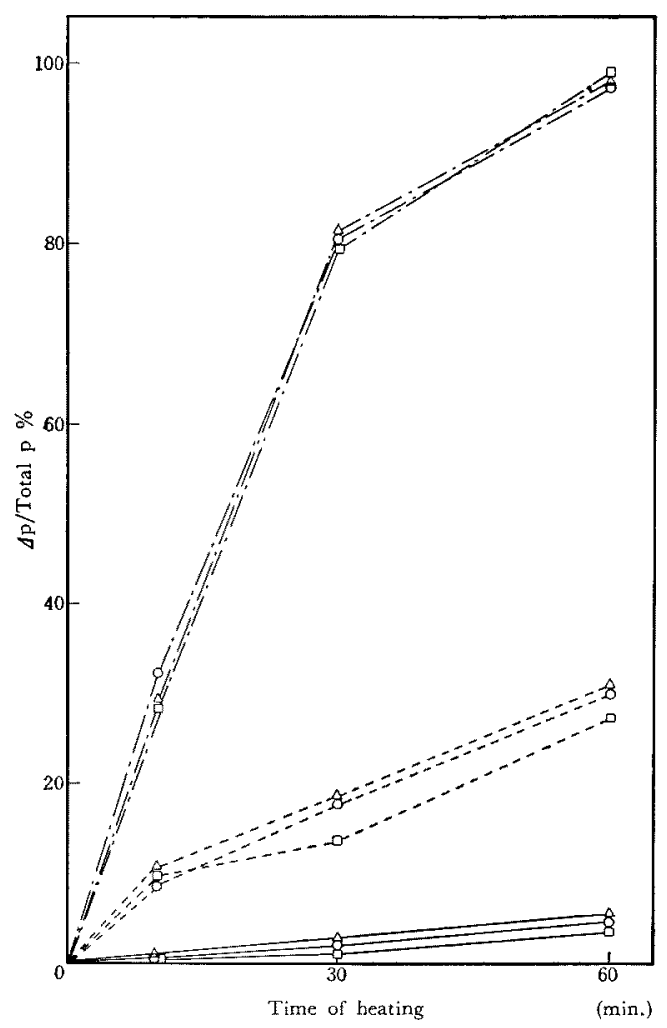

FIG. 2. Liberation of Phosphorus from caseins by Heating.

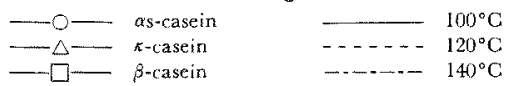

same in each casein fraction. The extent of liberation of phosphorus was much greater than that of NPN. By heating at $140^{\circ} \mathrm{C}$ for sixty minutes, nearly all phosphorus was released from caseins, while only a part of casein nitrogen became soluble.

\section{Digestion with Trypsin and Pepsin.}

After $1 \%$ sodium caseinate solution was heated at $120^{\circ} \mathrm{C}$ for thirty minutes, the $\mathrm{pH}$ was adjusted to 8.0 with a minimum amount of $1 \mathrm{~N}$ sodium hydroxide. Twenty $\mathrm{ml}$ of the caseinate solution was digested with $4 \mathrm{ml}$ of the trypsin solution, containing $5 \mathrm{mg}$ trypsin (Merck) per ml. For peptic digestion, the $\mathrm{pH}$ of the heated caseinate solution

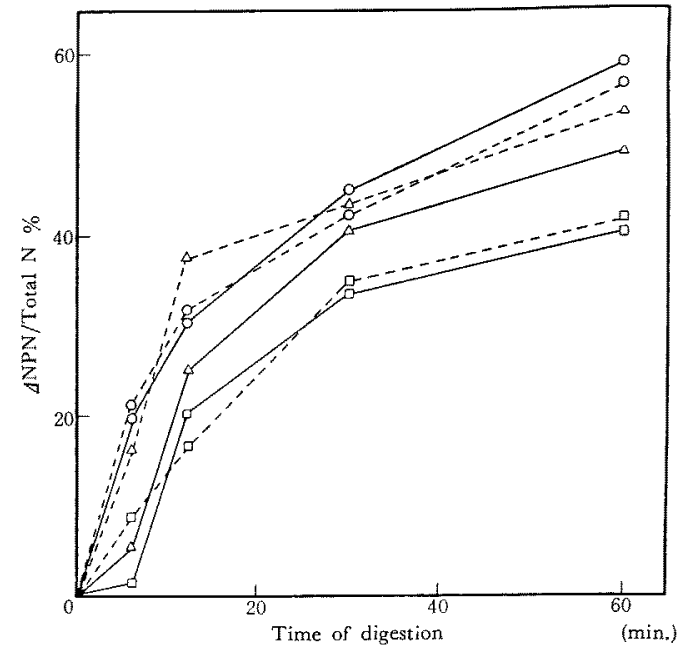

FIG. 3. Effect of Heat on the Tryptic Digestion of Caseins.
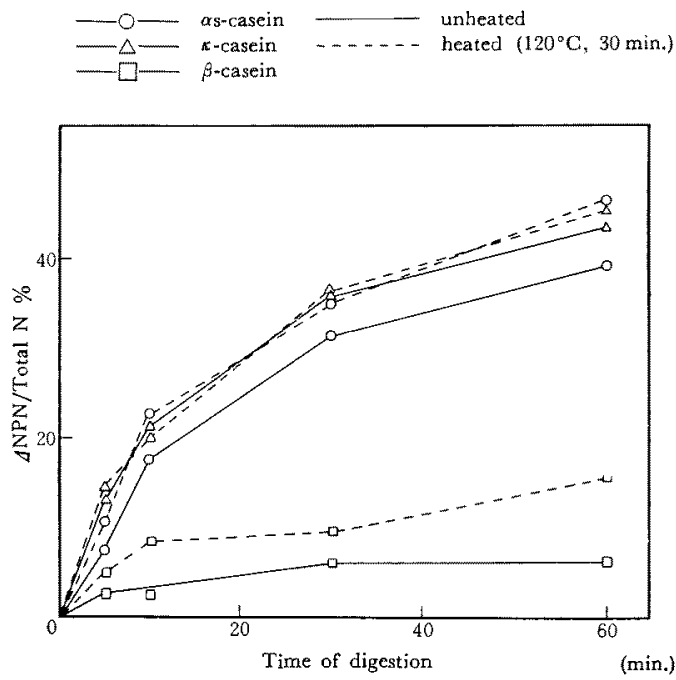

FIG. 4. Effect of Heat on the Peptic Digestion of Caseins.

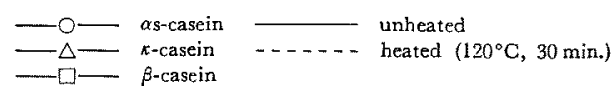

was brought to 2.2 with $1 \mathrm{~N}$ hydrochloric acid, and $20 \mathrm{ml}$ of the solution was digested with $4 \mathrm{ml}$ of the pepsin solution, containing $0.5 \mathrm{mg}$ pepsin (Mikuni, 1:5,000) per ml. After digestion at $35^{\circ} \mathrm{C}$ for periods up to sixty minutes, $5 \mathrm{ml}$ portions were taken from the mix- 
ture and mixed with $5 \mathrm{ml}$ of $24 \%$ TCA. The mixture was filtered and NPN was determined (Figs. 3, 4).

There was a difference in digestibility among the unheated casein fractions. The digestion rate with trypsin was highest in as-casein and lowest in $\beta$-casein. But the difference was not so great. The digestion of $\beta$-casein with pepsin was very slow as compared with those of as- and $\kappa$-caseins. The effect of heat treatment on tryptic digestion of as- and $\beta$-caseins was small, probably insignificant, but $\kappa$-casein became more digestible by heating. The heat treatment promoted the peptic digestion of $\alpha s$ - and $\beta$-caseins, but showed no significant effect on the digestion of $\kappa$-casein.

3. Solubility of Caseins in the Presence of Calcium Ion.

To $2 \mathrm{ml}$ of heated $1 \%$ as- and $\kappa$-caseinate solutions was added $0.1 \mathrm{ml}$ of $0.5 \mathrm{M}$ calcium chloride at $20^{\circ} \mathrm{C}$ to make final calcium concentration $0.024 \mathrm{M}$. After thirty minutes, the mixture was filtered and the nitrogen in the filtrate was determined (Fig. 5). In $\beta$-caseinate solution, even after it was heated, precipitate was not formed by adding calcium chloride at $20^{\circ} \mathrm{C}$. But at $35^{\circ} \mathrm{C}$, the addition of calcium chloride resulted in the formation of the precipitate of $\beta$-casein, which was filtered off at this temperature after standing at the same temperature for thirty minutes. Nitrogen of this filtrate was determined to calculate the solubility of $\beta$-casein, which was shown in Fig. 5.

The solubility of as- and $\beta$-caseins in the presence of calcium ion increased a little by heating at $120^{\circ} \mathrm{C}$ and increased remarkably at $140^{\circ} \mathrm{C}$. Unheated $\kappa$-casein was completely calcium soluble. The solubility of $k$-casein, however, decreased slightly after heating at $100^{\circ}$ or $120^{\circ} \mathrm{C}$ and greatly after heating at $140^{\circ} \mathrm{C}$.

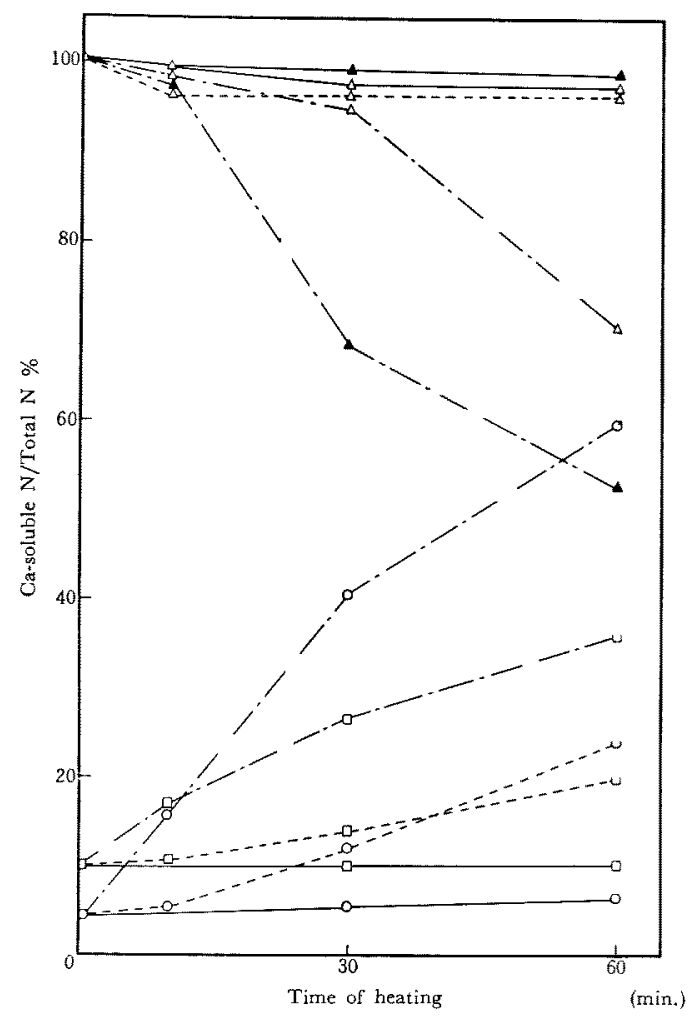

FIG. 5. Effect of Heat on the Solubility of Caseins in the Presence of CaIcium Ion.

$$
\begin{aligned}
& -\mathrm{O}-\alpha_{\mathrm{s} \text {-casein }} \longrightarrow 100^{\circ} \mathrm{C} \\
& \begin{array}{rrrr}
r-\operatorname{casein} & \ldots \ldots \ldots & 120^{\circ} \mathrm{C} \\
r-\operatorname{casein} & \ldots-\ldots \ldots & 140^{\circ} \mathrm{C}
\end{array}
\end{aligned}
$$
of milk.

The apparent increase in solubility of asand $\beta$-caseins in the presence of calcium ion is partly due to the liberation of non-protein nitrogeneous material by heating.

Another lot of $\kappa$-casein was prepared from a different batch of skim milk and examined in this experiment. The effect of heating at $100^{\circ}$ and $120^{\circ} \mathrm{G}$ on solubility of caseins in the presence of calcium ion was almost the same with two preparations of $\kappa$-casein. But by heating at $140^{\circ} \mathrm{C}$, solubility of two preparations of $\kappa$-casein changed differently (Fig. 5) . Zittle $^{8)}$ observed the difference in the prepa- 
rations of $\kappa$-casein obtained from different milks, and he thought that it was due to the presence of protease in milk. Another preparation of $\alpha$ s- and $\beta$-caseins was also examined, but the differences in the solubility in the presence of calcium ion between two preparations of as- and $\beta$-caseins when heated at $100^{\circ}, 120^{\circ}$ and $140^{\circ} \mathrm{C}$ were not so great as that observed in the case of $k$-casein heated at $140^{\circ} \mathrm{C}$.

4. Stabilizing Ability of $\kappa$-Casein.

$\kappa$-Casein stabilized as-casein against calcium ion. The effect of heat on this action was examined. Two per cent as-caseinate and one per cent $\boldsymbol{k}$-caseinate solutions were heated for thirty minutes separately. One $\mathrm{ml}$ of ${ }^{\kappa}$-casein was mixed with $1 \mathrm{ml}$ of as-casein and the mixture was allowed to stand for thirty minutes at $35^{\circ} \mathrm{C}$, followed by the addition of $0.1 \mathrm{ml}$ of $0.5 \mathrm{M}$ calcium chloride. The description of the appearance of the resultant mixture was given in Table 1. as-casein mixed with unheated $\kappa$-casein was stable against calcium ion, but the one mixed with heated $k$-casein was coagulated with calcium ion. In the mixture with $\kappa$-casein heated at $140^{\circ} \mathrm{C}$, the coagulation of as-casein was complete and gave clear supernatant. With $\kappa^{-}$ casein heated at $120^{\circ} \mathrm{C}$, the supernatant was a little turbid.

One $\mathrm{ml}$ of $1 \% \kappa$-caseinate solution heated for thirty minutes at different temperatures was mixed with $1 \mathrm{ml}$ of unheated $2 \%$ ascaseinate solution at $35^{\circ} \mathrm{C}$. After thirty minutes, $0.1 \mathrm{ml}$ of $0.5 \mathrm{M}$ calcium chloride was added to the mixture. The mixture was filtered and the nitrogen in the filtrate was determined (Fig. 6). The mixture of $k$-casein heated at $90^{\circ}$ or $100^{\circ} \mathrm{C}$ with as-casein turned milky by adding calcium ion. as-Casein mixed with $\kappa^{-}$-casein heated at $110^{\circ}$ or $120^{\circ} \mathrm{C}$ formed fine precipitates with calcium ion, and coarse precipitates were formed with $\kappa$-casein

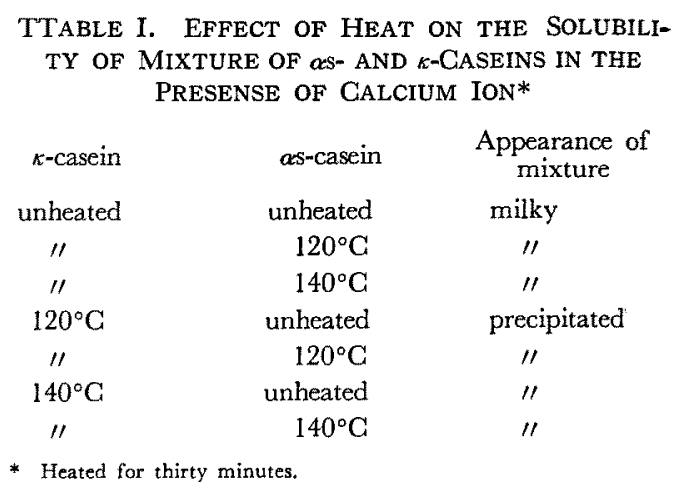

Heated for thirty minutes.

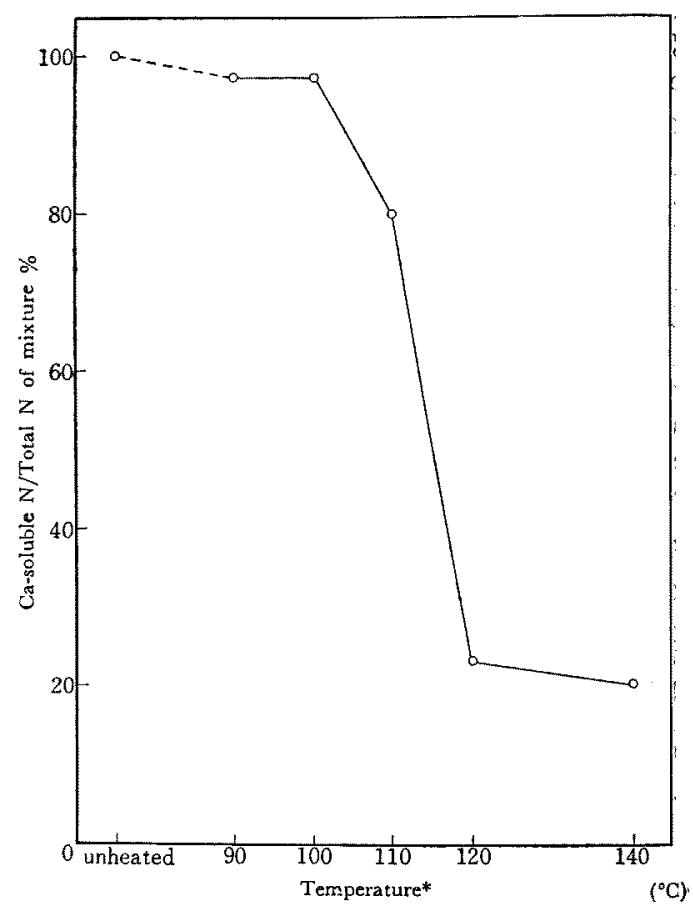

FIG. 6. Effect of Heat on Stabilizing Ability of $\kappa$-Casein.

* Heated for thirty minutes.

heated at $140^{\circ} \mathrm{C}$. When $\kappa$-casein was heated at $110^{\circ}, 120^{\circ}$ and $140^{\circ} \mathrm{C}$, the decreases of the soluble nitrogen were $20 \%, 77 \%$ and $80 \%$ of the total nitrogen of the mixture, respectively. These results revealed that the stabilization ability of $\kappa$-casein began to decrease by heating for thirty minutes at $100^{\circ}$ to $110^{\circ} \mathrm{C}$, 
and was lost almost completely at $120^{\circ} \mathrm{C}$.

\section{Sedimentation and Electrophoretic Analyses.}

The caseinate solutions were heated for thirty minutes at $100^{\circ}$ and $120^{\circ} \mathrm{C}$.

Fig. 7 and Table II show the sedimentation diagrams and constants for the heated casein fractions, respectively. A value of 0.728 was employed for the partial specific volume of as- and $\kappa$-caseins, and 0.741 for $\beta$-casein ${ }^{12}$ ). The changes of sedimentation constants by heating were less than $25 \%$. Any newly form-

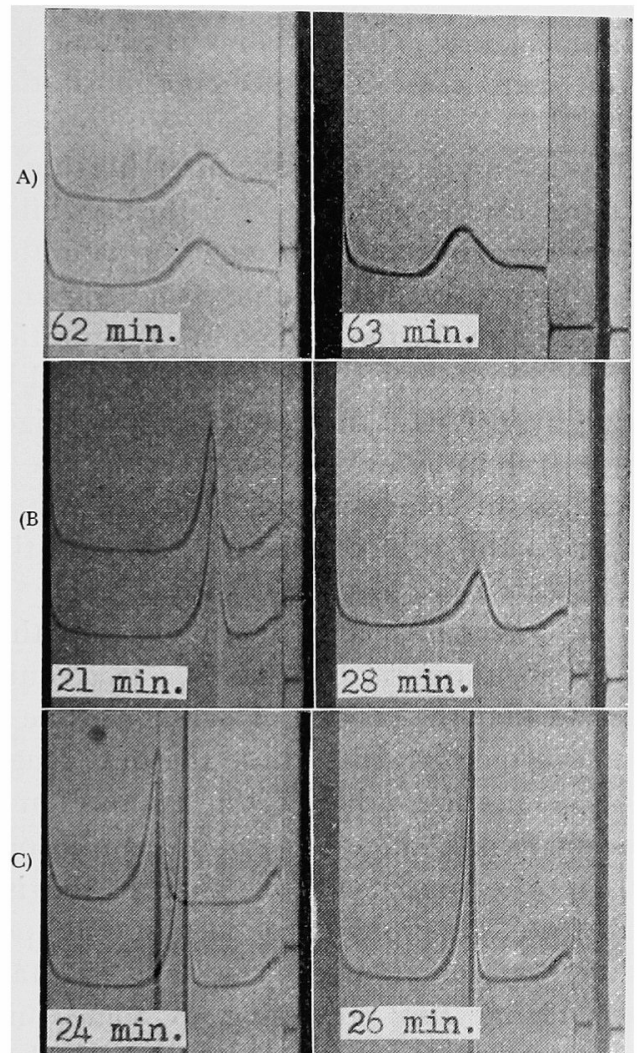

FIG. 7. Sedimentation Diagrams of (A) $\alpha$ s-Casein, (B) $\kappa$-Casein and $(\mathrm{C}) \beta$-Casein.

Run in phosphate buffer at pH 7.5 , ionic strength 0.2 , at $16^{\circ} \sim 18^{\circ} \mathrm{C}$. Protein concentration was about $1 \%$. Rotor speed was 59.800 r.p.m. Time was measured from the moment of attaining full speed and sedimentation is to the left. Right : unheated. Lower left : heated at $100^{\circ} \mathrm{C}$ for $30 \mathrm{~min}$. Upper left: heated at $120^{\circ} \mathrm{C}$ for $30 \mathrm{~min}$.

12) T.L. McMeckin, M.L. Groves and N.J. Hipp, J. Am. Chem. Soc., 71, 3298 (1949).
TABle II. SEdimentation Gonstants For HEATED CASEINS MEASURED FROM THE DIAGRAMS SHOWN IN FIG 7.

\begin{tabular}{lrrr} 
& unheated & $100^{\circ} \mathrm{C}$ & $120^{\circ} \mathrm{C}$ \\
\cline { 2 - 4 } Caseins & \multicolumn{3}{c}{$\mathrm{S}_{20, \mathrm{w}}$} \\
$\alpha s-$ & 6.3 & 5.2 & 4.9 \\
$\kappa-$ & 14.1 & 12.7 & 13.5 \\
$\beta-$ & 15.6 & 16.3 & 19.5
\end{tabular}

ed boundary was not observed after heating in each casein fraction. The sedimentation analyses were performed at room temperature, where $\beta$-casein is known to exist mostly in polymer ${ }^{13)}$. The presence of monomer in

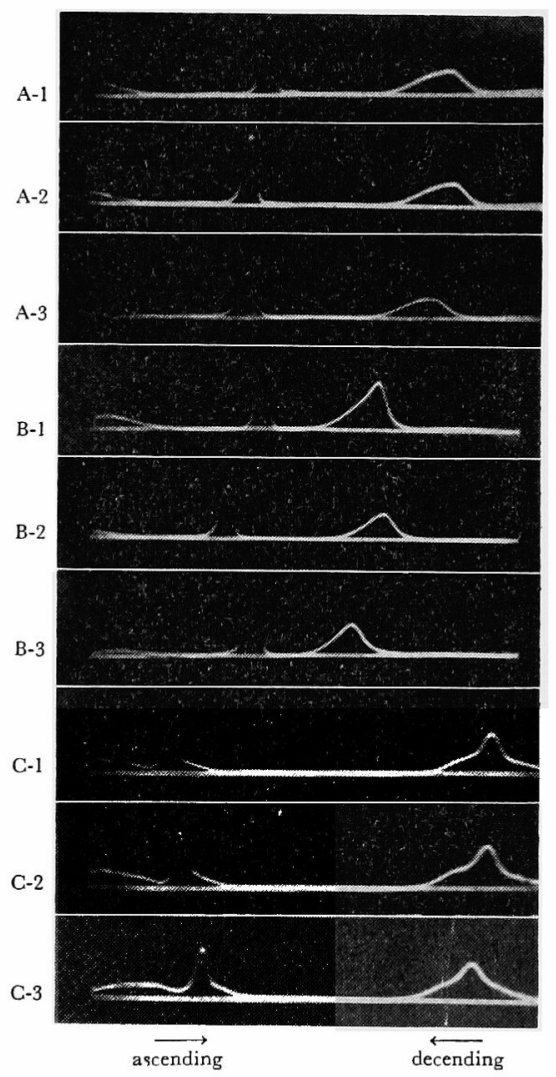

FIG. 8. Electrophoretic Patterns of (A) $\alpha s$-Casein, (B) $\kappa$-Casein, and (G) $\beta$-Casein.

Run in veronal buffer, $\mathrm{pH} 8.55$, ionic strength 0.1 , at $6^{\circ} \mathrm{C}$. Protein concentration was $2 \%$. Pictures were taken after sixty minutes' electrophoresis at $4 \mathrm{~mA} .1:$ unheated. 2: heated at $100^{\circ} \mathrm{C}$ for $30 \mathrm{~min} .3$ : heated at $120^{\circ} \mathrm{C}$ for $30 \mathrm{~min}$. 
Table HI. Relative Mobilities of Heated Caseins Calculated From the ElectroPhoretic PATternS (DECENDing) SHOWN IN FIG 8.

$\begin{array}{cccc}\text { Caseins } & \text { unheated } & 100^{\circ} \mathrm{C} & 120^{\circ} \mathrm{C} \\ \alpha \text { s- } & 100 & 95 & 95 \\ \kappa- & 100 & 96 & 87 \\ \beta- & 100 & 111 & 133\end{array}$

a small amount was observed but the figures were given for polymer in Table II. $\kappa$-Casein fraction also showed the presence of a slow sedimenting component, possibly $\lambda$-casein.

The electrophoretic patterns and relative mobilities were shown in Fig. 8 are Table III, respectively. The deformation of casein peaks, such as split, was not induced by heating. The heating resulted in a slight decrease of relative mobilities of as- and $\kappa^{-}$ caseins.

Heating at $140^{\circ} \mathrm{C}$ for thirty minutes made caseinate solutions too turbid to perform sedimentation and electrophoretic analyses.

\section{DISCUSSION}

Dephosphorization of casein took place much faster than the release of NPN during heating. This had been reported by Howat and Wright on whole casein ${ }^{5)}$ and by Belec and Jenness on $\alpha$ - and $\beta$-caseins ${ }^{9)} \quad$ Nearly all phosphorus was liberated from each casein fraction at $140^{\circ} \mathrm{C}$ for thirty minutes. Belec and Jenness reported that the rate of dephosphorization of $\alpha$-casein was a little higher than that of $\beta$-casein. Our results at $100^{\circ}$ and $120^{\circ} \mathrm{C}$ gave the similar tendency; the dephosphorization rate of $\beta$-casein was lower than that of as- or $\kappa$-casein. $\kappa$-Casein seemed to be dephosphorized slightly faster than as-casein. But the difference is probably within experimental error.

The differences in the liberation of NPN by heating were observed among casein fractions. The liberation of NPN from $\beta$-casein

13) R.A. Sullivan, M.M. Fitzpatrick, E.K. Stanton, R. Annino, G. Kissel and F. Palermite, Arch. Biochem. Biophys., 55, 455 (1955). was apparently lower than that from as- or $\kappa$-casein. $\beta$-Casein was also least hydrolysed with trypsin and pepsin. Christensen ${ }^{14)}$ reported that trypsin hydrolysed $\alpha$-casein better than $\beta$-casein. The promoting effects of heat on the proteolytic digestion were observed when $\kappa$-casein was digested with trypsin and as- and $\beta$-caseins with pepsin. In other cases, the effect of heat was slight.

The stability of $\kappa$-casein itself to calcium ion was hardly affected by heating at $120^{\circ} \mathrm{C}$ for thirty minutes. But its ability to stabilize as-casein against calcium ion was almost lost by the same treatment. Dephosphorization of $\kappa$-casein was about $20 \%$ and the release of NPN was only less than $3 \%$ after heating at the same condition. The stabilizing ability of $\kappa$-casein against as-casein seems to be rather heat sensitive and its loss due to heating may be associated with the change in configuration of $\kappa$-casein molecule which is accompanied by partial hydrolysis. Increase of tryptic digestion of $\kappa$-casein by heating may be also due to the change of configuration. But evidence is lacking in the present study to support this view.

Milk normally coagulates by heat within around 30 minutes at $130^{\circ} \mathrm{C}^{15)}$. It is quite probable that the change of $\kappa$-casein is one of the major factors which cause the heat coagulation of normal milk, if the assumption is made that the change of $\kappa$-casein in milk proceeds in the similar way to that in the isolated form. Results also suggest the possibility that the change of $\kappa$-casein will take place during the processing of some milk products such as evaporated milk, which is subjected to relatively severe heat treatment.

\section{SUMMARY}

The comparative studies were carried out on the effects of heat on the sodium $a s^{-}, k$ - and

14) L.R. Christensen, Arch. Biochem. Biophys., 53, 128 (1954).

15) J.C.D. White and D.T. Davies, J. Dairy Res., 25. 281 (1958). 
$\beta$-caseinate solutions, when they were heated at temperatures ranging from $100^{\circ}$ to $140^{\circ} \mathrm{C}$ for periods up to sixty minutes. The results obtained are as follows:

1. By heating, non-protein nitrogen was liberated most from $\kappa$-casein and least from $\beta$-casein. The phosphorus in each casein fraction was liberated almost completely by heating at $140^{\circ} \mathrm{C}$ for sixty minutes.

2. Trypsin, as well as pepsin, digested the unheated as- and $\kappa$-caseins better than $\beta$ casein. By heating, the digestibility of $\kappa^{-}$ casein by trypsin and of as- and $\beta$-caseins by pepsin were increased a little.
3. By heating at $120^{\circ} \mathrm{C}$ for thirty minutes, $\kappa$-casein lost its ability to stabilize as-casein against calcium ion.

4. The esdimentation constant and relative electrophoretic mobility of as- and $\kappa^{-}$ caseins decreased by heating, while those of $\beta$-casein increased. No newly formed component was observed in heated casein both by sedimentation and electrophoretic analyses.

Acknowledgement. This study was supported by the research grant of The Morinaga Hoshikai, to whom the authors wish to express their sincere thanks. 